\title{
Robert Mayer: Conservation of Energy and Venous Blood Colour
}

\author{
Teresa Rocha-Homem \\ Centro de Filosofia das Ciências da Universidade de Lisboa, Lisbon, Portugal \\ Email: teresarhomem@gmail.com
}

Received 20 May 2015; accepted 13 July 2015; published 17 July 2015

Copyright (C 2015 by author and Scientific Research Publishing Inc.

This work is licensed under the Creative Commons Attribution International License (CC BY). http://creativecommons.org/licenses/by/4.0/

(c) (i) Open Access

\begin{abstract}
The concept of conservation and transformation of energy was proposed by the 19th century doctor, Robert Mayer. This concept derives from a clinical observation. During the 1st centennial celebrations, the medical profession posed the question of whether Mayer had indeed observed what he claimed and took as the basis of the principle of conservation of energy: if the colour of venous blood in the tropics was lighter than in colder regions, then this was a result of a higher oxygen consumption to maintain body temperature. In this paper, it was shown that, based on Mayer's data and contemporary physiology, this observation could indeed have occurred but for a different reason.
\end{abstract}

\section{Keywords}

Mayer, Doctor, Energy, Conservation of Energy, Contemporary Physiology

\section{Introduction}

Robert Mayer (1814-78) was a very unusual doctor to whom is owed the discovery of the principle of conservation of energy. The foundation of this discovery lies in a clinical observation. In 1840, Robert Mayer embarked on a boat trip to Java as the ship's doctor. The crew had an uneventful trip but on arrival they suffered from a pulmonary infection. When performing phlebotomy, Mayer was surprised to find that the venous blood was lighter in colour than observed in Germany ${ }^{1}$. He tells us that he suspected to have inadvertently perforated an

\footnotetext{
1“Während einer hunderttägigen Seereise war bei der aus 28 Köpfen bestehenden Equipage kein erheblicher Krankheitsfall vorgekommen; wenige Tage aber nach unserer Ankunft auf der Rhede von Batavia verbreitete sich epidemisch eine acute (katarrhalisch-entzündliche) Affection der Lungen. Bei den reichlichen Aderlässen, welche ich machte, hatte aus der Armvene gelassene Blut eine ungemeine Röthe, so, dass ich der Farbe nach glauben konnte, eine Arterie getroffen zu haben. (...) Bei einer reichlichen Aderlässe, welche ich zwei Monate nach unserer Ankunft in Java an einem kräftigen, von einer Leberentzündung befallenen Matrosen anstellte, fandich eine normale schwarze Farbe des Blutes“ (Mayer, 1845: pp. 84-85).
} 
artery, but he confirmed this was not the case.

Mayer then postulated that if venous blood was lighter in colour in the tropics as compared with colder areas of the globe, then this was due to the higher oxygen consumption in order to maintain body temperature.

In 1914, on the occasion of the author's centennial commemoration, Mayer's clinical observation, driver of the idea of conservation and transformation, was pondered with some detail by the medical profession.

Several papers were produced as part of these celebrations, and some of these posed the question of whether human venous blood was lighter in colour in the tropics than in central Europe, especially during winter.

In 1914, Exner remarks not finding any references to this topic in contemporary and past literature (Jentsch, 1916). In 1916’s Die Naturwissenschaften, Jentsch highlights a passage of Johann Autenrieth's (1772-1835) book, Handbuch der menschlichen Physiologie (1801), shown to him by Ebstein, which reads: "also in the human being, the colour of venous blood is similar to that of arterial blood in the summer” (Jentsch, 1916: p. 91). In 1954, Farber studied some 18th century's authors in which this connection was ascertained. Adair Crawford (1748-1795), in Experiments and Observations on Animal Heat and the Inflammation of Combustible Bodies, 1778, supported the influence of external heat on the colour of blood. He immersed a dog in reasonably hot water and after half an hour "venous blood hue was very similar to that of arterial blood" (Farber, 1954: p. 6).

In 1840, when travelling to Java, Indonesia, Mayer observed that the venous blood of the crew had a lighter colour than that of people living in colder regions. Mayer considered that this variation was due to a smaller difference in temperature between an organism and its environment in the tropics, and therefore a lower oxygen requirement and consumption to keep the organism warm. Hence, there was a lighter colour for venous blood. This correlation between oxygen consumption and carbon dioxide production was in contradiction with the uncertainty over blood colour that existed at that time. During the third and fourth decades of the 19th century, physiologists attributed the function of removing excess carbon dioxide from the blood to the liver, through bile. This theory was based on the concept that blood in warm climates is darker than in cold climates because there is lower oxygen saturation and less carbon dioxide release from the blood (Caneva, 1993). This is due, firstly to the notion that the difference in temperature between the organism and the environment was unrelated to the animal heat source, i.e., the inexistence of a correspondence between oxygen consumption and carbon dioxide production and, secondly, that the liver was the organ which eliminates carbon dioxide from venous blood through bile, and in warmer climates there was more bile in venous blood and more carbon dioxide. As such, in warmer climates there was lower blood oxygen saturation and less carbon dioxide release. In this way, Mayer's observations were surprising. He expected to observe darker venous blood in the tropics than in colder climates.

According to Mayer himself, the origin of his finding lay in his observation, or apparent observation, of a difference in blood colour. Anyway, based on this, he developed the idea for the principle of conservation of energy. The discovery of one of the greatest principles in science originated from the following rationale. If human venous blood is lighter in colour in warmer areas of the globe, such as the tropics, than in colder regions, like Europe, then this will be because, in the latter, more oxygen consumption is required to maintain body temperature. This indicates that, in order to achieve something, something will have to be spent. On his return to Europe, Mayer sent a scientific paper to the journal Annalen der Physik und Chemie, known then as Poggendorff's Annals, the editor's name. The paper was not published, and the editor did not even reply to Mayer. Several years later, after Poggendorff's death, the paper was found amongst his documents and published. In 1842, Mayer submits another paper to Liebig's journal Annalen der Chemie und Pharmazie, and this was published. Here originates the commemoration held in 1914 by the medical community. It is as a result of the six pages of this paper that Mayer is attributed the merit of finding the principle of conservation of energy.

\section{Explanatory Model of the Colour of Venous Blood}

To try to address the discussion over venous blood colour in the tropics, still unproven to this day, I have formulated an explanatory hypothesis based on Mayer's own data.

To try and understand Mayer's observation, we must analyse current theories about blood colour. Lighter or darker blood colour is a result of oxygen content and carbon dioxide bound to the haemoglobin molecule: oxyhaemoglobin and carboxyhaemoglobin respectively (cf. Braunwald et al., 2001).

Let us then build an explanatory contemporary model for venous blood colour. The lighter colour in blood is attributed to haemoglobin's oxygen level or the binding of an oxygen atom to a haemoglobin molecule, resulting in oxyhaemoglobin. In colder climates there is generally the higher food consumption and therefore more glucose metabolism during the Krebs cycle with the production of ATP, the major source of heat in a living organ- 
ism (Guyton \& Hall, 2006). There is the release of a carbon dioxide molecule which binds to the haemoglobin molecule, resulting in a carboxyhaemoglobin molecule that gives a darker colour to the blood.

The process of glucose metabolism occurs in mitochondria and the gas swap over of oxygen and carbon dioxide occurs at a tissue capillary level. At the lung level, there is only a gas swap between inhaled oxygen and carbon dioxide, expelled through exhalation, without metabolism of the glucose in food. The inhaled air, rich in oxygen, goes to the lungs where the gas swaps occur in the alveoli with the production of carbon dioxide that is then expelled through exhalation.

Venous blood containing carboxyhaemoglobin resulting from gas swaps at capillary level, and which originated from glucose metabolism in the Krebs cycle, goes into the right atrium, leaves the right ventricle and is carried to the lung, through the pulmonary artery, where it is oxygenated, i.e. the oxygen in inhaled air binds to the haemoglobin molecule by a swap over with carbon dioxide, resulting in a molecule of oxyhaemoglobin. The oxygenated arterial blood is transported through the pulmonary veins into the left atrium of the heart. Then it is pumped to the left ventricle and from there, it is carried to the entire body through the aorta.

Differences in venous blood colour stem from a balance between oxygen consumption and carbon dioxide production. This balance was established by Theodore Saussure (1804) in his work about germination in vegetables, Rechercheschimichessur la vegetation.

The lower the glucose metabolism during the Krebs cycle, the less molecules of carboxyhaemoglobin are formed and transported in venous blood, and therefore the less dark the blood. This is what happens in the tropics, where there is less food consumption, lower difference in temperature between the organism and the environment and less glucose metabolism.

One hypothesis for a theoretical model for living organisms from a contemporary perspective can be proposed. For this it becomes necessary to consider some aspects. Living organisms are comprised of organs, the organs by tissues, and the latter by cells. A cell is composed of a nucleus surrounded by a cytoplasmic membrane or cell membrane. Cytoplasm is the area between the nucleus and the cell membrane, and it contains the cell organelles. The mitochondrion, the cellular respiration unit, is the organelle that must be highlighted at this stage, since it is where the chemical process of metabolism of glucose in the citric acid cycle, or Krebs cycle, takes place. The physiological process of the sodium-potassium electrogenic pump occurs at the cell membrane.

Mayer's idea of the transformability of mechanical energy (work) into heat, and vice-versa, finds a parallel on the current theories on the production of animal heat. The source of animal heat or energy is ATP, or adenosine triphosphate, of which the main source is the respiratory chain in the mitochondria.

Without neglecting the complexity of events that take place during the Krebs cycle, we can make use of the elements that can be significant for the subsequent construction of our theoretical model. Thus, the Krebs cycle is a chain of chemical reactions of the metabolism of glucose, the main products of which are carbon dioxide $\left(\mathrm{CO}_{2}\right)$ and the corresponding reduced $\mathrm{FADH}_{2}$ and $\mathrm{NADH}$, electron carriers.

In the chemical process of metabolism of glucose during the Krebs cycle, there is the release of energy with the production of one ATP molecule. ATP released during the Krebs cycle is reused in a new Krebs cycle. ATP results from the bonding between phosphate and ADP.

But can we really say that energy is converted into ATP? There is a displacement in the respiratory chain: $\mathrm{FADH}_{2}$ and $\mathrm{NADH}$ transfer their electrons during the respiratory chain, and ultimately they are accepted by molecular oxygen $\left(\mathrm{O}_{2}\right)$ which is reduced to water $\left(\mathrm{H}_{2} \mathrm{O}\right)$. A proton gradient is generated during the electron transfer in the respiratory chain, with protons being pumped from the mitochondrial matrix into the intermembrane space. When the electrons flow back into the mitochondrial matrix through ATP, there is the production of ATP, i.e., the production of ATP is a result from this electron displacement.

How to reconcile work (energy) and ATP, which are of different natures? The solution lays in contemplating this relationship in terms of a balance. This supports nicely Mayers's thesis of a correspondence between phenomena.

Another aspect is the sodium-potassium electrogenic pump. The mechanism behind the sodium-potassium pump relies on the following. At rest, the cell membrane has a negative resting potential of $-90 \mathrm{mV}$ inside the cell $^{2}$. The difference in potential between the inside and the outside of the cell triggers the sodium-potassium pump, and there is a swap over of sodium and potassium across the cell membrane, with 2 potassium ions entering the cell and 3 sodium ions leaving it. The higher number of sodium ions leaving the cell results in a more

\footnotetext{
2“The resting membrane potential of large fibers when not transmitting nerve signals is about -90 millivolts. That is, the potential inside the fiber is 90 millivolts more negative than the potential in the extracellular fluid on the outside of the fiber” (Guyton \& Hall, 2006: p. 59).
} 
negative membrane potential inside the cell, i.e., the membrane potential rises from $-86 \mathrm{mV}$ during the process of passive diffusion to $-90 \mathrm{mV}$ as a result of the active transport of the sodium-potassium pump. At this moment the action potential is triggered in two stages. The membrane becomes very permeable to sodium, and sodium ions enter the cell. The interior of the cell becomes positive. This is the membrane depolarization phase. The sodium channels then start to close up and the potassium channels open up; potassium leaves the cell until a new negative membrane potential is reached. This is the membrane repolarisation phase. Calcium swaps with potassium, as does sodium. Sodium is pumped out of the cell spending ATP (Guyton \& Hall, 2006: pp. 45-71).

This way the model can be represented schematically by three interconnected levels (Figure 1):

1st level cell membranes (sodium-potassium pump).

2nd level mitochondria (Krebs cycle).

3rd level capillaries.

These three levels are in different planes and reflect a chain of events. Sodium and potassium ion interchange occurs across the cell membranes. Sodium is pumped to the outside spending ATP and there is the release of a carbon dioxide molecule. Carbon dioxide binds to a haemoglobin molecule at tissue capillary level producing carboxyhaemoglobin. This molecule is transported by the vena cava to the heart and lungs where the gas swaps occur between oxygen in inhaled air and carbon dioxide which will be exhaled. Oxygen binds to haemoglobin producing oxyhaemoglobin which is then transported via the aorta to the entire body. At tissue capillary level, oxygen will enter a new Krebs cycle. This topic is explored in detail in Rocha-Homem (2014: pp. 88-94).

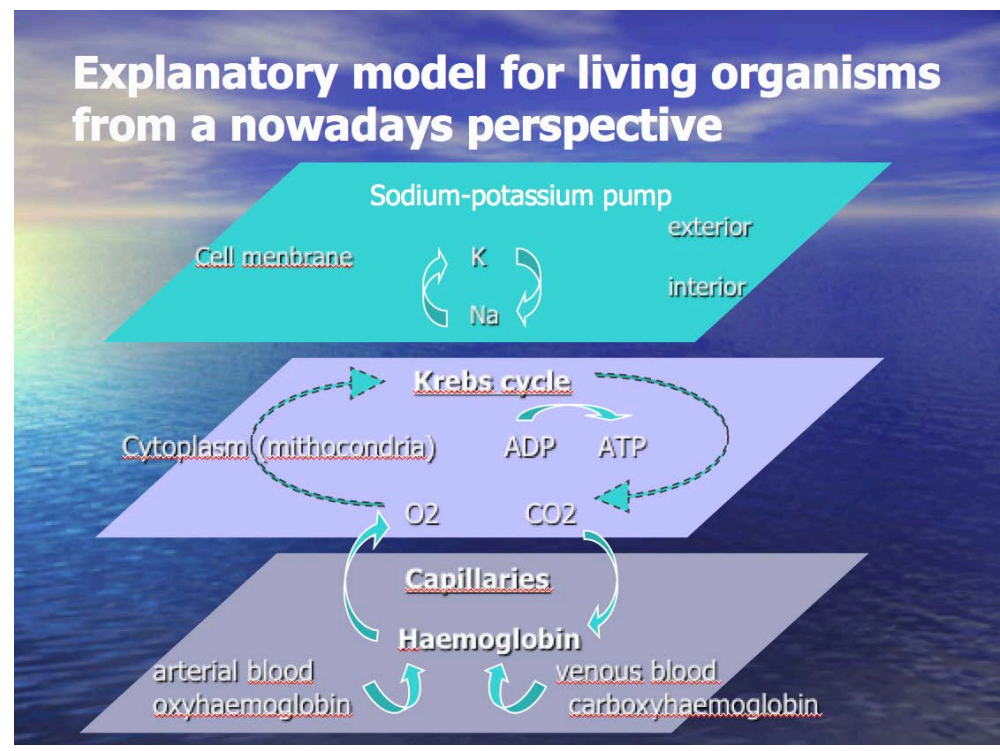

Figure 1. Explanatory model for living organisms.

\section{Conclusion}

Mayer's clinical observation in 1840 that blood colour in the tropics was lighter than in colder regions was the motive behind the idea of the conservation of energy.

In 1914, the medical community raised the question of whether Mayer did observe what he claimed.

In an attempt to answer this question, I produced an explanatory model based on Mayer's own data and on contemporary physiology about the colour of venous blood. This model can be outlined in the following fashion. The base of biological phenomenon is the electrogenic sodium-potassium pump. Sodium is pumped out of the cell spending ATP and a carbon dioxide molecule is produced. Carbon dioxide binds to haemoglobin producing carboxyhaemoglobin which confers a darker colour to blood, at peripheral capillary level. Carboxyhaemoglobin is transported by the vena cava to the lungs where carbon dioxide swaps over with inhaled oxygen. Oxygen binds to haemoglobin producing oxyhaemoglobin which gives the blood a lighter colour. Oxyhaemoglobin travels to the heart and is distributed to the entire body via the aorta. At peripheral capillary level, oxygen will enter a new Krebs cycle.

In the tropics, there is generally less food consumption and therefore lower glucose metabolism during the 
Krebs cycle; there is a smaller difference in temperature between the organism and the environment. These are all venous hyperoxemia conditions and they can theoretically corroborate Mayer's observation. They do not corroborate, however, Mayer's explanation.

An obvious question that begs to be answered is: are there actual colour differences in the venous blood of humans in the tropics and in temperate regions? Such a rigorous measurement, apparently never made, could further enrich our understanding of the merits of Mayer's observations and the historical value of his theory.

\section{Acknowledgements}

I am grateful to Prof. Ricardo Lopes Coelho for his guidance through out this research and to Prof. Manuel E. Dos Santos for his contributions. I am also grateful to my husband António Melo for his constant support. Two anonymous reviewers provided useful comments.

\section{References}

Braunwald, E., Fauci, A. S., Kasper, D. L., Hauser, S. L., Longo, D. L., \& Jameson, J. L. (2001). Harrison’s Principles of Internal Medicine (15th ed.). New York, NY: McGraw-Hill.

Caneva, K. (1993). Robert Mayer and the Conservation of Energy. Princeton: Princeton University Press.

Farber, E. (1954). The Colour of Venous Blood. Isis, 45, 3-9. http://dx.doi.org/10.1086/348281

Guyton, A., \& Hall, J. (2006). Textbook of Medical Physiology (11th ed.). Philadelphia: Elsevier.

Jentsch, E. (1916). Zur Geschichte der Entdeckung Julius Robert Mayer. Die Naturwissenschaften, 4, 90-93. http://dx.doi.org/10.1007/BF01497222

Mayer, J. R. (1842). Bemerkungen uber die Krafte der unbelebten Natur. Annalen der Chimie und Pharmazie, 42, $233-240$. http://dx.doi.org/10.1002/jlac.18420420212

Mayer, J. R. (1845). Die Organische Bevegung in ihrem Zusammenhange mit dem Stoffwechsel. Heilbronn. (In Mayer 1978).

Rocha-Homem, T. (2014). Energia e Medicina: Mayer e Helmholtz. PhD Dissertation, Lisbon: Faculdade de Ciências da Universidade de Lisboa.

Saussure, T. (1804). Rechercheschimiquessur la végétation. Paris: Chez la V Nion. 